J Arid Land (2015) 7(4): 501-513

doi: $10.1007 / \mathrm{s} 40333-015-0041-0$

jal.xjegi.com; www.springer.com/40333

\title{
Impact of climate change on the streamflow in the glacierized Chu River Basin, Central Asia
}

\author{
MA Changkun ${ }^{1}$, SUN Lin², LIU Shiyin ${ }^{3}$, SHAO Ming'an², LUO Yi ${ }^{2,4^{*}}$ \\ ${ }^{1}$ College of Natural Resources and Environment, Northwest A\&F University, Yangling 712100, China; \\ ${ }^{2}$ Key Laboratory of Ecosystem Network Observation and Modeling, Institute of Geographic Sciences and Natural Resources Research, \\ Chinese Academy of Sciences, Beijing 100101, China; \\ ${ }^{3}$ State Key Laboratory of Cryospheric Sciences, Cold and Arid Regions Environmental and Engineering Research Institute, Chinese \\ Academy of Sciences, Lanzhou 730000, China; \\ ${ }^{4}$ Xinjiang Institute of Ecology and Geography, Chinese Academy of Sciences, Urumqi 830011, China
}

\begin{abstract}
Catchments dominated by meltwater runoff are sensitive to climate change as changes in precipitation and temperature inevitably affect the characteristics of glaciermelt/snowmelt, hydrologic circle and water resources. This study simulated the impact of climate change on the runoff generation and streamflow of Chu River Basin (CRB), a glacierized basin in Central Asia using the enhanced Soil and Water Assessment Tool (SWAT). The model was calibrated and validated using the measured monthly streamflow data from three discharge gauge stations in CRB for the period 1961-1985 and was subsequently driven by downscaled future climate projections of five Global Circulation Models (GCMs) in Coupled Model Inter-comparison Project Phase 5 (CMIP5) under three radiative forcing scenarios (RCP2.6, RCP4.5 and RCP8.5). In this study, the period 1966-1995 was used as the baseline period, while 2016-2045 and 2066-2095 as the near-future and far-future period, respectively. As projected, the climate would become warmer and drier under all scenarios in the future, and the future climate would be characterized by larger seasonal and annual variations under higher RCP. A general decreasing trend was identified in the average annual runoff in glacier $(-26.6 \%$ to $-1.0 \%)$, snow $(-21.4 \%$ to $+1.1 \%)$ and streamflow $(-27.7 \%$ to $-6.6 \%)$ for most of the future scenario periods. The projected maximum streamflow in each of the two future scenarios occurred one month earlier than that in the baseline period because of the reduced streamflow in summer months. Results of this study are expected to arouse the serious concern about water resource availability in the headwater region of CRB under the continuously warming climate. Changes in simulated hydrologic outputs underscored the significance of lowering the uncertainties in temperature and precipitation projection.
\end{abstract}

Keywords: glacier; snow; meltwater runoff; climate change; hydrologic modeling

Citation: MA Changkun, SUN Lin, LIU Shiyin, SHAO Ming'an, LUO Yi. 2015. Impact of climate change on the streamflow in the glacierized Chu River Basin, Central Asia. Journal of Arid Land, 7(4): 501-513. doi: 10.1007/s40333-015-0041-0

Most rivers originating from mountain regions are often referred to as "water towers" (Immerzeel et al., 2012). This is especially true for Central Asia where most rivers originate from the Tianshan Mountains (Sorg et al., 2012). In Central Asia, large amounts of water exist as snow/glacier in headwater regions of river basins and melt waters variably contribute to streamflow in the catchments. As snow/glacier is sensitive to climate change, its effect on streamflow un- der warming climatic conditions has raised significant interest in both the scientific community and decision-making bodies (Li et al., 2013).

Observed changes in glacier/snow have been generally attributed to rising temperatures in recent decades. Cruz et al. (2007) reported a global temperature rise of $1-2^{\circ} \mathrm{C}$ in the last century. Studies also noted a temperature rise of $0.39^{\circ} \mathrm{C} / 10 \mathrm{a}$ in Central Asia in 1979-2011 but with significant local heterogeneity

\footnotetext{
*Corresponding author: LUO Yi (E-mail: luoyi.cas@gmail.com) Received 2014-09-08; revised 2014-11-26; accepted 2014-12-09

(C) Xinjiang Institute of Ecology and Geography, Chinese Academy of Sciences, Science Press and Springer-Verlag Berlin Heidelberg 2015
} 
(Unger-Shayesteh et al., 2013; Hu et al., 2014). By analyzing changes in glacier area in Ala-Archa and Ak-Shirak massifs in the northern and central Tianshan Mountains, Aizen et al. (2007) noted that reduction in glacier cover in the peripheral of northern Tianshan Mountains was about 3\% higher than that in the central Tianshan Mountains due to temperature differences. Also due to increasing summer temperatures and glacier recession in the region has accelerated since the 1970s.

A comprehensive review by Unger-Shayesteh et al. (2013) displayed regionally heterogeneous changes in glacier cover in the central Tianshan Mountains. The stronger losses of glacier cover in the northern and eastern margins of Tianshan Mountains were largely explained by differences in the patterns of climate change and the characteristics of glaciation in the sub-regions. Decreases were also noted in snow pack thicknesses and snow cover durations in the mountain region, attributed to the reduced solid precipitation and enhanced snowmelt driven by climate warming (Aizen et al., 1997; Sorg et al., 2012).

Climate change has also resulted in changes in flows of glacier/snow-fed rivers originating from the Tianshan Mountains. Analysis of climatic and hydrological data from 110 stations in the Tianshan Mountains suggested decreasing annual runoff in the second half of the $20^{\text {th }}$ century (Aizen et al., 1997). However, Tao et al. (2011) and Sorg et al. (2012) noted increasing runoff in several catchments in the inner ranges and stable runoff in the outer ranges of the mountains in recent decades. There is an increasing trend in the application of hydrological models driven by observed glacier, snow, streamflow and climatic data in analyzing the impacts of climate change on hydrological processes in glacier/snow-dominated catchments (Huang et al., 2010; Vaghefi et al., 2014).

Significant research effort has been directed into analyzing the characteristics of rivers originating from the Tianshan Mountains in Central Asia (e.g. Hagg et al., 2006, 2007; Siegfried et al., 2011; Malsy et al., 2012). Most of this effort has focused mainly on large river basins (e.g. Amu Darya and Syr Darya basins) in the region (Siegfried et al., 2011; Immerzeel et al., 2012; Lutz et al., 2013), but little has been done about Chu River Basin (CRB). Although relatively small,
CRB is a critical source of water use for Kyrgyzstan. Hydrological studies in this basin have far too often been driven by lumped glacier model (e.g. Hydrologiska Byråns Vattenavdelning (HBV) or its variant) simulations. Physically-based distributed hydrological model simulations could enhance a deeper understanding of the impacts of climate change on glacier/snow hydrological processes in the CRB.

The main objective of this study was to analyze the impacts of climate change on hydrological processes in the headwater region of CRB using a physically-based distributed hydrological model under projected climate change scenarios from Global Circulation Models (GCMs) in Coupled Model Inter-comparison Project Phase 5 (CMIP5).

\section{Materials and methods}

\subsection{Study area}

Chu River is the main river of CRB $\left(73^{\circ} 24^{\prime}-77^{\circ} 04^{\prime} \mathrm{E}\right.$, $\left.41^{\circ} 45^{\prime}-43^{\circ} 11^{\prime} \mathrm{N}\right)$ and is one of the longest rivers in Kyrgyzstan. Chu River starts from the middle ranges of Tianshan Mountains and runs all the way to Moyynqunm Desert where it disappears in abundant sands. The study area $\left(75^{\circ} 50^{\prime} \mathrm{E}, 42^{\circ} 43^{\prime} \mathrm{N} ; 1,249-4,617 \mathrm{~m}\right.$ asl) is in the headwater region of CRB that is in the upstream of the catchment outlet and has a drainage area of $9,548 \mathrm{~km}^{2}$ (about $15.3 \%$ of the total area of CRB; Fig. 1). The area has a cool continental climate. The average temperatures in the coldest month of January and the hottest month of July are $-16^{\circ} \mathrm{C}$ and $13^{\circ} \mathrm{C}$, respectively. Precipitation in the basin is unevenly distributed in time and space, with a long-term (1951-2005) average annual amount of $425 \mathrm{~mm}$ and $70 \%$ of it falling in April to August.

There are three main tributaries in the upstream region of Chu River (Table 1). Precipitation in the catchments of these tributaries was derived from gridded APHRODITE datasets for 1951-2007. Significant differences were noted in annual precipitation and glacier cover among the catchments of the three tributaries. The heterogeneous climatic and glacial conditions suggest the degree of complexity of hydrologic response to climate change in the study area.

\subsection{Hydrological model}

The Soil and Water Assessment Tool (SWAT) model 


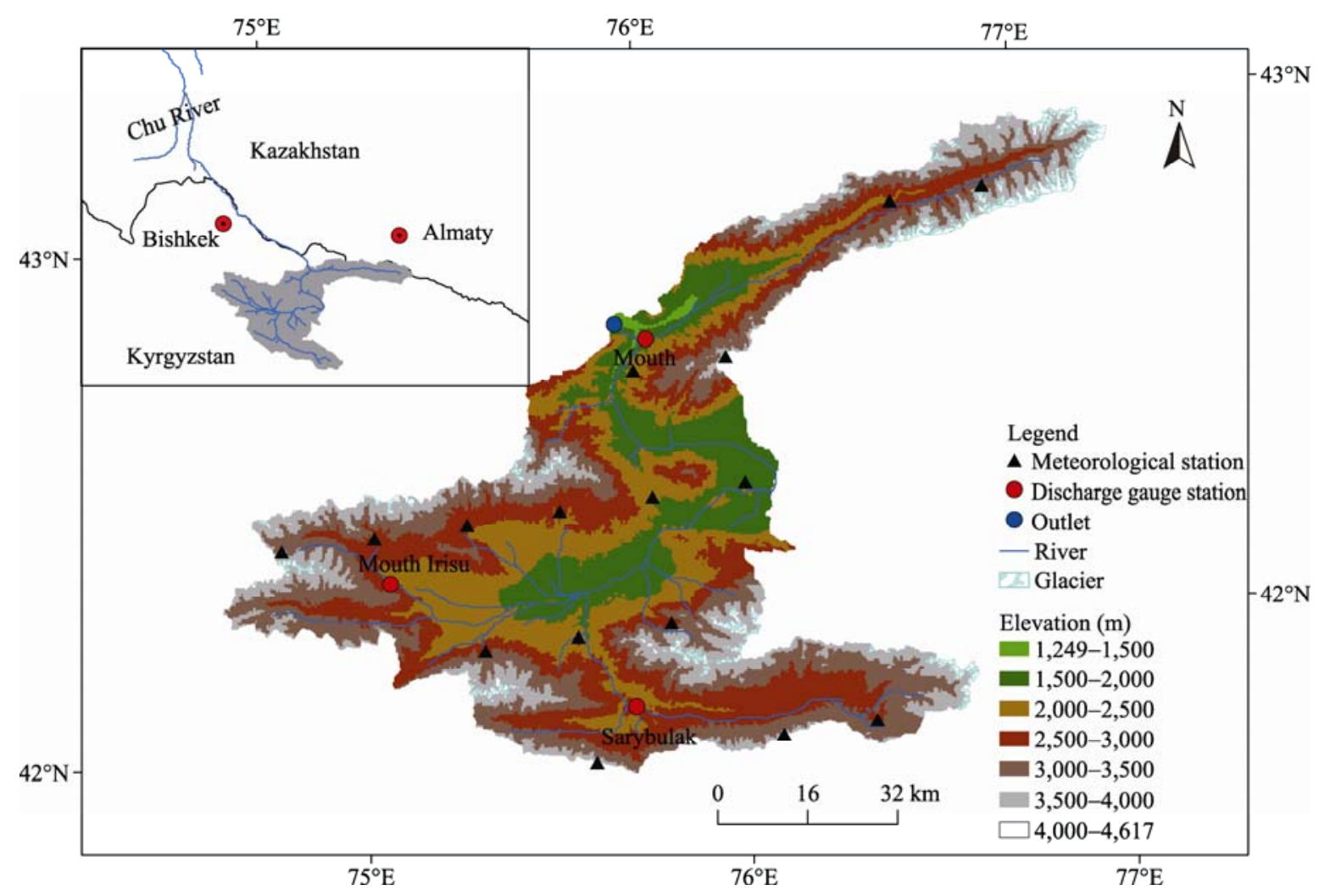

Fig. 1 Map of the study area depicting the locations of the meteorological and discharge gauge stations in the headwater region of CRB (Chu River Basin)

Table 1 The area, glacier cover, elevation range, mean annual runoff and precipitation of the catchments in the headwater region of CRB (Chu River Basin)

\begin{tabular}{|c|c|c|c|c|c|c|c|}
\hline \multirow{2}{*}{ Discharge gauge station } & \multirow{2}{*}{$\begin{array}{l}\text { Area } \\
\left(\mathrm{km}^{2}\right)\end{array}$} & \multirow{2}{*}{$\begin{array}{c}\text { Glacier cover } \\
(\%)\end{array}$} & \multicolumn{3}{|c|}{ Elevation (m) } & \multirow{2}{*}{$\begin{array}{l}\text { Runoff } \\
(\mathrm{mm} / \mathrm{a})\end{array}$} & \multirow{2}{*}{$\begin{array}{l}\text { Precipitation } \\
\quad(\mathrm{mm} / \mathrm{a})\end{array}$} \\
\hline & & & Minimum & Maximum & Mean & & \\
\hline Mouth (in Chon-Kemin River) & 1,863 & 7 & 1,362 & 4,617 & 2,990 & 374 & 529 \\
\hline Sarybulak (in Karkudzhur River) & 1,401 & 2 & 2,266 & 4,607 & 3,437 & 175 & 334 \\
\hline Mouth Irisu (in Karkol River) & 407 & 4 & 2,420 & 4,355 & 3,388 & 391 & 477 \\
\hline
\end{tabular}

Note: Data of runoff were the mean annual runoff for 1966-1995, and data of precipitation were the mean annual precipitation for 1951-2007 from gridded APHRODITE datasets.

is a temporally continuous and physically-based semi-distributed hydrological model that is widely used in catchments under different climatic and management conditions (Gassman et al., 2007, 2014). To account for basin-scale heterogeneities, SWAT subdivides a basin into multiple sub-basins based on topography and hydrological response unit (HRU). HRU integrates unique soil, land use and slope into an entity of uniform hydrological processes. Runoff in each HRU can be routed through the tributaries or channel to the main outlet of the basin. The detailed description of SWAT was documented by Neitsch et

\section{al. (2005).}

SWAT does not simulate glacier processes, which are crucial for glacier-dominated catchments. To account for basin-scale glacier hydrology, Luo et al. (2013) developed and incorporated a glacier hydrology module into SWAT2005 code. The glacier module can simulate glacier mass balance and dynamics for individual glaciers. While the module uses a volume-area scaling method for glacier area change estimation, elevation bands are adopted for glacier mass balance. Each glacier in a given elevation band is treated as a complete HRU. The calculations for the 
individual glaciers are then scaled up to the entire simulation domain (Chen and Ohmura, 1990). The glacier-module SWAT tested on the Manas River Ba$\sin$ (which is on the northern slope of East Tianshan Mountains) proved to be robust in simulating distributed glacier hydrology at a catchment scale. To distinguish the enhanced SWAT from the original model, we hereafter term our enhanced one as SWAT-RSG (RSG: rain, snow and glacier).

The runoff simulation by SWAT-RSG model was calibrated and validated by comparing simulated streamflow with observed values at hydrological gauge stations in the study area. The simulated daily discharge were scaled up to outlet values and compared with monthly mean discharge measured at Mouth, Mouth Irisu and Sarybulak gauge stations (Fig. 1). The calibration and validation analyses of the model were evaluated using coefficient of determination $\left(R^{2}\right)$, Nash-Sutcliffe efficiency (NSE) and percent bias index (PBIAS), which can be calculated as follows.

$$
R^{2}=\frac{\sum_{i=1}^{n}\left(\mathrm{Q}_{i}^{\text {obs }}-\mathrm{Q}_{\mathrm{obs}}^{\text {mean }}\right)\left(\mathrm{Q}_{i}^{\text {sim }}-\mathrm{Q}_{\text {sim }}^{\text {mean }}\right)}{\sqrt{\sum_{i=1}^{n}\left(\mathrm{Q}_{i}^{\text {obs }}-\mathrm{Q}_{\mathrm{obs}}^{\text {mean }}\right)^{2}} \sqrt{\sum_{i=1}^{n}\left(\mathrm{Q}_{i}^{\text {sim }}-\mathrm{Q}_{\text {sim }}^{\text {mean }}\right)^{2}}} .
$$

Where $R^{2}$ is the coefficient of determination, $\mathrm{Q}_{i}^{\text {obs }}$ is the $i^{\text {th }}$ observed flow, $\mathrm{Q}_{i}^{\text {sim }}$ is the $i^{\text {th }}$ simulated flow, $\mathrm{Q}_{\mathrm{obs}}^{\text {man }}$ is the observed mean flow, $Q_{\text {sim }}^{\text {man }}$ is the simulated mean flow, and $n$ is the total number of observed flow.

$$
\mathrm{NSE}=1-\frac{\sum_{i=1}^{n}\left(\mathrm{Q}_{i}^{\mathrm{obs}}-\mathrm{Q}_{i}^{\mathrm{sim}}\right)^{2}}{\sum_{i=1}^{n}\left(\mathrm{Q}_{i}^{\text {sim }}-\mathrm{Q}_{\mathrm{obs}}^{\text {mean }}\right)^{2}} .
$$

Where NSE is the Nash-Sutcliffe efficiency. NSE measures the level of consistency of measured values with predicted values and is generally ranged from $-\infty$ to 1 with NSE=1 as the optimal value (Nash and Sutcliffe, 1970).

$$
\text { PBIAS }=\frac{\sum_{i=1}^{n}\left(\mathrm{Q}_{i}^{\text {obs }}-\mathrm{Q}_{i}^{\text {sim }}\right)^{2} \times 100}{\sum_{i=1}^{n} \mathrm{Q}_{i}^{\text {obs }}} .
$$

Where PBIAS is the percent bias between observed and simulated values. PBIAS measures the relative error in percentage between simulated and measured values (Moriasi et al., 2007). The positive value denotes underestimation; negative value indicates overestimation and zero means optimal estimation.

\subsection{Model setup}

\subsubsection{Sub-basin and HRU delineation}

The 90-m-resolution Digital Elevation Model (DEM) data from Shuttle Radar Topography Mission were used to delineate the catchment and HRU as well as derivations of stream slope and channel width. Also 300-m-resolution land use data were derived from the latest version of satellite maps of the European Space Agency (http://due.esrin.esa.int/globcover) and reclassified based on the land cover classification system of Anderson et al. (1976). The land use type in the study area was grouped into twelve classes, i.e. bare land (44\%), range-grass (21\%), post-flood cropland (10\%), generic agricultural land (7\%), pasture (13\%), mixed forest $(3 \%)$ and others $(2 \%)$. The type of "others" includes evergreen forest, glacier, open water, settlement, mixed wetland and range bush. Glacier data were derived from the Tianshan Glacier Dataset v.1 (http://www.asiacryoweb.org/wiki/bin/view/Home.We bHome).

The Tianshan Glacier Dataset v.1 includes two glacier inventories: one for the 1970s and the other for the 2000s. The inventory for the 1970s was built from declassified KH-9 satellite images, while the inventory for the 2000s was constructed from ETM+, ASTER and SRTM satellite data. The dataset was updated with point data for glaciers in the World Glacier Inventory (WGI). The updates included point data for glacier in the headwater region of CRB not available in the Tianshan Glacier Dataset v.1. A total of 315 glaciers were identified in the catchment, with a total area of $220 \mathrm{~km}^{2}$. The compiled glacier extent was used to initialize the simulation at a starting point of 1961 .

The soil types were determined using version 1.2 of Harmonized World Soil Database (HWSD) at spatial resolution of $1,000 \mathrm{~m}$. Leptosol accounts for $46.1 \%$ of the soils in the study area, followed by kastanozem (28.3\%), calcisol (17.2\%), outcropped rock $(5.7 \%)$, chernozem $(2.5 \%)$ and open water $(0.2 \%)$. The soil column was divided into two layers in this study, i.e. the upper layer $(0-30 \mathrm{~cm})$ and the deeper layer $(30-100 \mathrm{~cm})$. The parameters of both soil layers were calculated from HWSD soil texture and organic matter as proposed by Saxton and Rawls (2006).

Additional digital data were resampled from DEM, land use and soil type at a uniform spatial resolution. 
Then the study area was delineated into 67 sub-basins and 610 HURs by using ARCSWAT and on the basis of land use, soil type and slope.

\subsubsection{Meteorological data}

Meteorological data were compiled from public databases (Sherrield et al., 2006; Yatagai et al., 2012). Precipitation data were obtained from Asian Precipitation Highly-Resolved Observational Data Integration Towards Evaluation of Water Resources (APHRODITE) and temperature (maximum and minimum) data were derived from Princeton's Global Meteorological Forcing Dataset (PGMFD). APHRODITE dataset is a long-term (starting from 1951 to date) continental-scale gridded daily product interpolated from daily gauge-measured precipitation in Asia with a spatial resolution of $0.25^{\circ}$. PGMFD was constructed by reanalysis of combined data from National Centers for Environmental Prediction and National Center for Atmospheric Research (NCEP-NCAR) with a suite of global observation-based datasets and spatial resolution of $0.5^{\circ}$. Daily air temperature data were bilinearly interpolated at $0.25^{\circ}$ resolution from the grid cell centers in the $0.5^{\circ}$ PGMFD gridded temperature dataset. In this study, altitudinal lapse rates of precipitation and temperature were derived from these gridded meteorological datasets.

\subsubsection{Discharge data}

River discharge was mainly used for model parameterization. Monthly discharge data $\left(\mathrm{m}^{3} / \mathrm{s}\right)$ at Mouth (Chon-Kemin River), Mouth Irisu (Karakol River) and Sarybulak (Karkudzhur River) for 1961-1985 were collected from http://webworld.unesco.org/water/ihp/ $\mathrm{db} /$ shiklomanov/part'4/former\%20ussr/index4.html. As stated earlier, agricultural and post-flood crops could be irrigated by water withdrawal from streams. In Chon-Kemin, Karakol and Karakudzhur sub-catchments, the crop covers are $2.6 \%, 0.8 \%$ and $2.9 \%$, respectively.
The annual precipitation in these sub-catchments was 334-592 mm during 1966-1995. This suggested minimal irrigation intake from the streams, which was considered negligible in the calibration and validation analyses.

\subsection{Climate change scenarios}

There is a total of 39 Global Circulation Models in Coupled Model Inter-comparison Project Phase 5 (CMIP5). Wu et al. (2014) evaluated the performances of these models in terms of projected temperature and precipitation in arid Northwest China by comparing the projected values with ground observations. As no similar work available for the study area, this study used the listed top 5 models in Table 2 to drive the SWAT-RSG to project impacts of future climate change on hydrological processes in the CRB. Temperature and precipitation outputs of the models for RCP2.6 (radiative forcing peaks at approximately $3 \mathrm{~W} / \mathrm{m}^{2}$ before 2100 and then declines), RCP4.5 (stabilizes radiative forcing at $4.5 \mathrm{~W} / \mathrm{m}^{2}$ in the year 2100 without ever exceeding that value) and RCP8.5 (rising radiative forcing pathway leading to $8.5 \mathrm{~W} / \mathrm{m}^{2}$ by 2100) scenarios were downscaled to $0.25^{\circ}$ spatially and to daily values temporally using the delta change factor method (Anadhi et al., 2011; Chen et al., 2011).

The downscaling included three steps (Anadhi et al., 2011): (1) estimation of mean values of each GCMsimulated baseline and future climate; (2) calculation of additive change factors for temperature and multiplicative change factors for precipitation; and (3) application of the change factors (temperature and precipitation) to local values to get future local-scale values. The downscaled temperature and precipitation data for each scenario and model were used to drive the parameterized SWAT-RSG simulations for the period spanning from 1951 through 2100. Ensemble

Table 2 A list of the Global Circulation Models used in this study

\begin{tabular}{clll}
\hline Model & IPCC model ID & Modeling group and country & Reference \\
\hline 1 & CCSM4 & National Center for Atmospheric Research, USA & Gent et al. (2011) \\
2 & CMCC-CM & Centro Euro-Mediterraneo per i Cambiamenti Climatici, Italy & Scoccimarro et al. (2011) \\
3 & CNRM-CM5 & National Center for Meteorological Research, France & Voldoire et al. (2011) \\
4 & IPSL-CM5A-LR & Institute Pierre Simon Laplace, France & Dufresne et al. (2013) \\
5 & MPI-ESM-LR & Max Planck Institute for Meteorology, Germany & Giorgetta et al. (2013) \\
\hline
\end{tabular}


averages of simulated climate and hydrological outputs for 1966-1995, 2016-2045 and 2066-2095 were compared to determine the decadal changes under each climate scenario. Then the climate and hydrological outputs of each GCM model and scenario represented uncertainties in the climate projections and model results (Arnell et al., 2004; IPCC 2007; Meehl et al., 2007).

\section{Results and discussions}

\subsection{Model calibration and validation}

The observed monthly flow data for 1961-1985 were split into two periods: one for the model calibration period of 1961-1975 and the other for the validation period of 1976-1985. Based on other study (Luo et al., 2013), the most sensitive parameters of SWAT-RSG model in Tianshan Mountains are those related to glacier/snowmelt and baseflow. The variation ranges of the parameters were compiled from the previous literature (i.e. Zhang et al., 2006; Hagg et al., 2007; Cui et al., 2010) and the parameters manually calibrated through evaluation of the performance indices stated earlier. The simulated changes in glacier area were also assessed against with literature values from Narama et al. (2010) and Unger-Shayesteh et al. (2013) for both the calibration and validation analyses. The calibrated parameters and parameter indices are respectively given in Table 3 and Table 4.

For the three discharge gauge stations, NSE values for the calibration and validation analyses were higher than 0.75 and therefore rated as very good (e.g. Morasi et al., 2007). PBIAS values for the calibration and validation periods were lower than $20 \%$ and therefore rated as good (e.g. Moriasi et al., 2007; Rossi et al., 2008; Mengistu et al., 2012). Regression analysis also suggests that the simulated monthly discharge generally agreed well with the observed values (Fig. 2). It should be noted that discharge was underestimated for high gauge values as depicted in Fig. 3, largely attributed to the interpolation weakness.

Lapse rates of both temperature and precipitation were used to derive the temperature and precipitation at different altitude bands. It was generally assumed precipitation at the base station continued to increase along altitudinal profile. Thus the altitudinal temperature and precipitation profiles were estimated from base station values and lapse rate. The lapse rate approach could underestimate or even entirely miss large temperature and precipitation events at high elevation bands, resulting in less glacier/snowmelt or rainfall-generated runoff. However, as the SWAT-RSG model in most cases successfully captured peak flows

Table 3 Ranges of parameters of SWAT-RSG (rain, snow and glacier) in the headwater catchment of CRB

\begin{tabular}{|c|c|c|c|}
\hline Parameter & Description & Range & Optimal value \\
\hline GW_DELAY & Groundwater delay time (days) & $1-500$ & 25 \\
\hline ALPHA_BF & Baseflow alpha factor (days) & $0-1$ & 0.015 \\
\hline SMFMX & Maximum snowmelt rate per year $\left(\mathrm{mm} /\left({ }^{\circ} \mathrm{C} \cdot \mathrm{d}\right)\right)$ & $0-10$ & 2.5 \\
\hline SMFMN & Minimum snowmelt rate per year $\left(\mathrm{mm} /\left({ }^{\circ} \mathrm{C} \cdot \mathrm{d}\right)\right)$ & $0-10$ & 1 \\
\hline Bgmlt, 6 & Glaciermelt degree-day factor on 21 June $\left(\mathrm{mm} /\left({ }^{\circ} \mathrm{C} \cdot \mathrm{d}\right)\right)$ & $0-10$ & 7 \\
\hline Bgmlt, 12 & Glaciermelt degree-day factor on 21 December $\left(\mathrm{mm} /\left({ }^{\circ} \mathrm{C} \cdot \mathrm{d}\right)\right)$ & $0-10$ & 3 \\
\hline Cgmlt, 6 & Glacier sublimation factor on 21 June $\left(\mathrm{mm} /\left({ }^{\circ} \mathrm{C} \cdot \mathrm{d}\right)\right)$ & $0-1$ & 0.8 \\
\hline Cgmlt, 12 & Glacier sublimation factor on 21 December $\left(\mathrm{mm} /\left({ }^{\circ} \mathrm{C} \cdot \mathrm{d}\right)\right)$ & $0-1$ & 0.2 \\
\hline
\end{tabular}

Table 4 Performance indices of SWAT-RSG parameters in the headwater catchment of CRB

\begin{tabular}{|c|c|c|c|c|c|c|}
\hline \multirow{2}{*}{ Discharge gauge station } & \multicolumn{3}{|c|}{ Calibration } & \multicolumn{3}{|c|}{ Validation } \\
\hline & NSE & PBIAS (\%) & $R^{2}$ & NSE & PBAIS (\%) & $R^{2}$ \\
\hline Mouth & 0.83 & 8 & 0.85 & 0.77 & 17 & 0.84 \\
\hline Mouth Irisu & 0.85 & 1 & 0.86 & 0.86 & -4 & 0.87 \\
\hline Sarybulak & 0.81 & 14 & 0.85 & 0.79 & 4 & 0.80 \\
\hline
\end{tabular}

Note: NSE, Nash-Sutcliffe efficiency; PBAIS, percent bias index; $R^{2}$, coefficient of determination. 

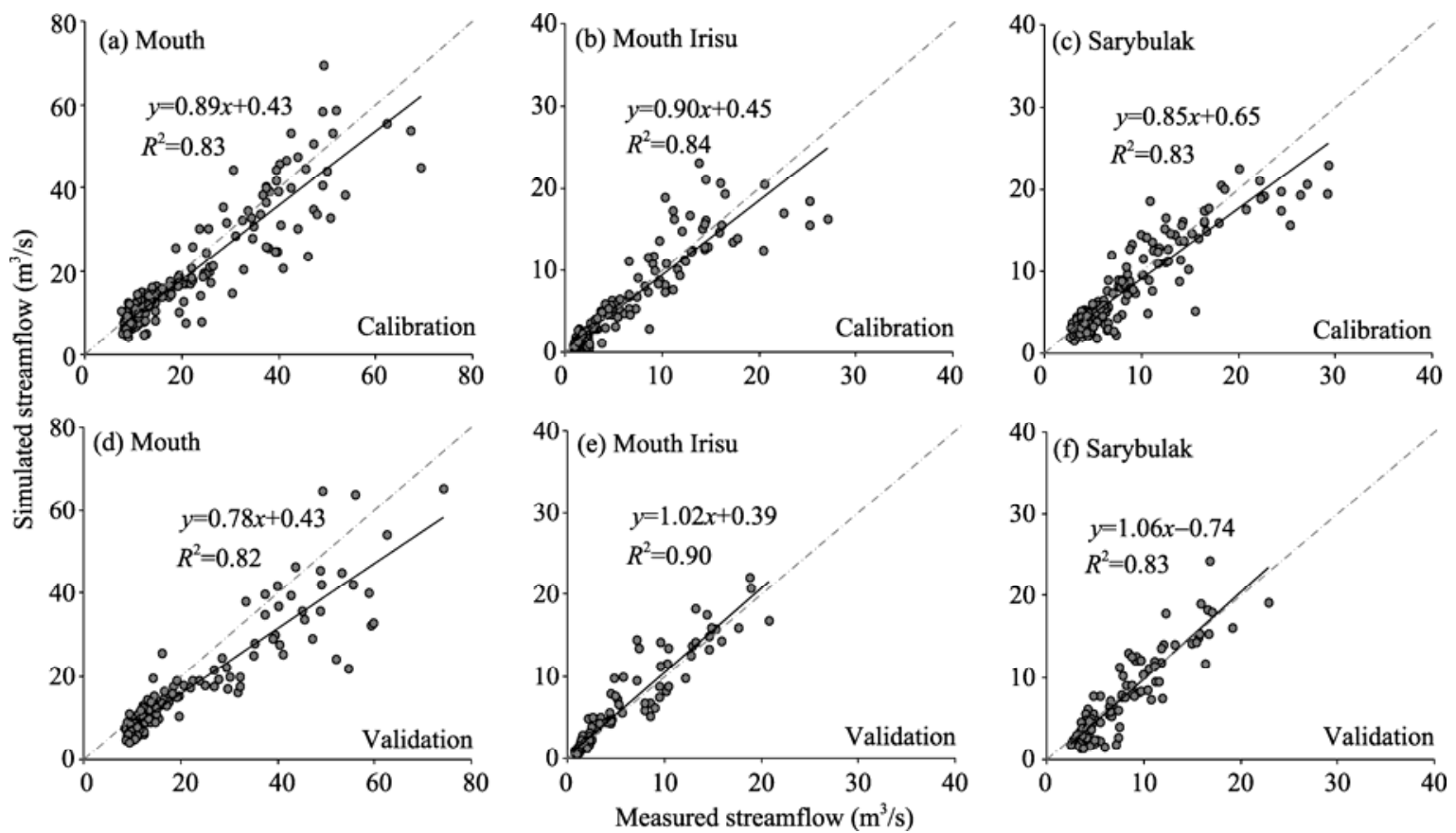

Fig. 2 Regression analysis of simulated and measured monthly streamflow for the calibration period of 1961-1975 (a-c) and validation period of 1976-1985 (d-f) for the Mouth, Mouth Irisu and Sarybulak discharge gauge stations of CRB
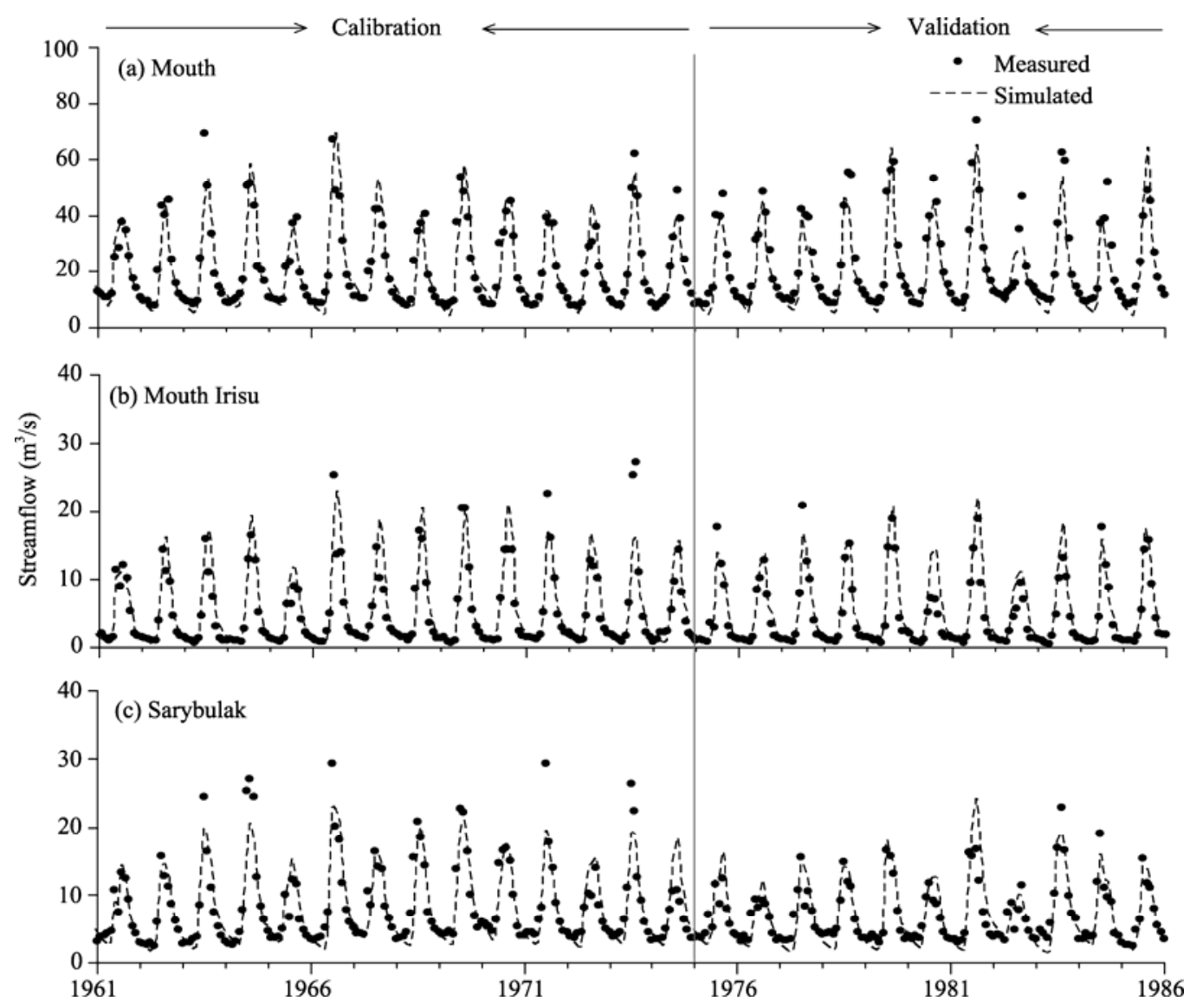

Fig. 3 Comparison of simulated and measured monthly streamflow for the calibration period of 1961-1975 and validation period of 1976-1985 for the Mouth (a), Mouth Irisu (b) and Sarybulak (c) discharge gauge stations of CRB 
in the region, suggesting that any under-/over-estimation could have been limited.

\subsection{Climate change in headwater catchment of CRB}

Changes in temperature and precipitation in the future periods of 2016-2045 and 2066-2095 relative to the baseline period 1966-1995 are given in Table 5 and the monthly values are also plotted in Figs. 4 and 5 . Change values in temperature and precipitation are the seasonal or annual averages of the five GCMs ensembles for the three periods. Precipitation in the summer and autumn and the annual precipitation showed a decreasing trend for all the three scenarios. For the near-future period of 2016-2045, significant differences are noted among the different scenarios in the pattern of precipitation decline. For the far-future period of 2066-2095, obvious differences are also noted among the scenarios. For precipitation, the decreasing trend in projected average annual values will decrease from the near-future period 2016-2045 to the far-future period 2066-2095 for the low radiative forcing pathway of RCP2.6 scenario, while they are projected to increase for the medium and strong radiative forcing pathways of RCP4.5 and RCP8.5 scenarios in the future. For temperature, the changes are obviously noted for different radiative forcing pathways under different future periods. For the near-future pe- riod of 2016-2045, the differences in the pattern of temperature increase are not significant among the different scenarios, while they are obviously noted for the far-future period of 2066-2095. The stronger the radiative forcing pathway is, the larger the changes in precipitation and temperature are.

\subsection{Seasonality and decadal trends of projected runoff}

\subsubsection{Seasonal runoff}

In the middle or the end of the $21^{\text {st }}$ century, there will be obvious changes in the seasonal meltwater runoff from glaciers and snowcover as well as the streamflow (Fig. 6). There are two snowmelt seasons in the headwater catchment of CRB (Figs. 6a-c). The first season starts in late January to early February and ends in late July to early August. Snowmelt in the first season increases first until early to mid-April and then decreases. The second season follows the first season. Snowmelt in the second season increases first and then decreases with the maximum value occurring in early October. Seasonal distribution patterns of snowmelt will change under climate change in the future.

Compared to the baseline period, snowmelt runoff is projected to increase between early January to mid-April and early October to late December, and decrease between mid-April and late September for all climate change scenarios in the future period. The projected changes in snowmelt runoff are attributed to

Table 5 Projected seasonal and annual changes in precipitation and temperature based on mean values of the five GCMs ensembles for the future periods of 2016-2045 and 2066-2095 relative to the baseline period of 1966-1995 under RCP2.6, RCP4.5 and RCP8.5 scenarios

\begin{tabular}{|c|c|c|c|c|c|c|}
\hline \multirow{2}{*}{ Season/Annual } & \multicolumn{3}{|c|}{ Precipitation change $(\%)$} & \multicolumn{3}{|c|}{ Temperature change $\left({ }^{\circ} \mathrm{C}\right)$} \\
\hline & $\mathrm{RCP} 2.6$ & $\mathrm{RCP} 4.5$ & RCP8.5 & $\mathrm{RCP} 2.6$ & $\mathrm{RCP} 4.5$ & RCP8.5 \\
\hline & \multicolumn{6}{|c|}{ Ensemble mean of 2016-2045 } \\
\hline Spring (Mar-May) & -0.6 & 0.1 & 1.7 & 1.7 & 1.7 & 1.9 \\
\hline Summer (Jun-Aug) & -14.3 & -11.6 & -13.0 & 2.0 & 2.0 & 2.2 \\
\hline Autumn (Sep-Nov) & -11.7 & -4.7 & -10.4 & 2.0 & 2.0 & 2.4 \\
\hline Winter (Dec-Feb) & 5.5 & 8.0 & 12.5 & 1.6 & 1.8 & 2.0 \\
\hline \multirow[t]{2}{*}{ Annual (Jan-Dec) } & -7.4 & -4.7 & -5.2 & 1.8 & 1.9 & 2.1 \\
\hline & \multicolumn{6}{|c|}{ Ensemble mean of 2066-2095 } \\
\hline Spring (Mar-May) & 4.6 & 5.0 & 0.4 & 1.6 & 2.9 & 5.1 \\
\hline Summer (Jun-Aug) & -6.1 & -19.5 & -33.9 & 1.9 & 3.4 & 5.8 \\
\hline Autumn (Sep-Nov) & -6.6 & -2.2 & -16.6 & 2.3 & 3.3 & 5.8 \\
\hline Winter (Dec-Feb) & 8.5 & 14.0 & 19.1 & 1.8 & 3.1 & 5.3 \\
\hline Annual (Jan-Dec) & -0.9 & -5.3 & -14.5 & 1.9 & 3.2 & 5.5 \\
\hline
\end{tabular}



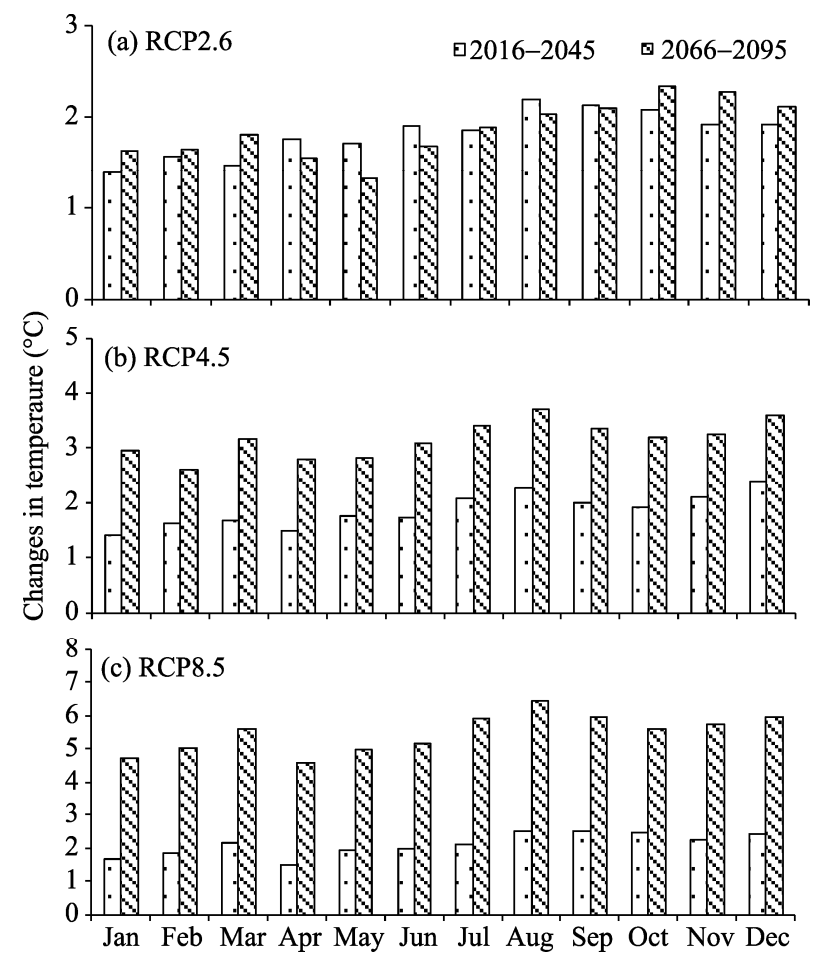

Fig. 4 Projected changes in mean monthly temperature for the future periods of 2016-2045 and 2066-2095 relative to the baseline period 1966-1995 under RCP2.6 (a), RCP4.5 (b) and RCP8.5 (c) scenarios

the increased precipitation in spring and winter and decreased precipitation in summer and autumn, but also the increased temperature in the future. Then the stronger the radiative forcing scenario is, the more significant the changes in snowmelt intensity are. Furthermore, it was interesting to note that the timing and amount of maximum snowmelt slightly changed under all the climate change scenarios for the periods 2016-2045 and 2066-2095. This is attributed to the combined effects of changes in precipitation and temperature during these periods.

Glacial runoff is defined as the sum of runoff over the glacier. Glacial runoff in the headwater catchment of CRB is expected to decrease in the future. This is the result of the accelerated retreat of glaciers in the studied area of CRB under warming climate scenarios. Areal shrinkage of glaciers may play the key role in glacial runoff reductions although ablation increases due to warming. Furthermore, decreases in precipitation in summer and autumn are expected to exceed increases in precipitation in spring and winter, implying reduced glacier mass accumulation in the region.
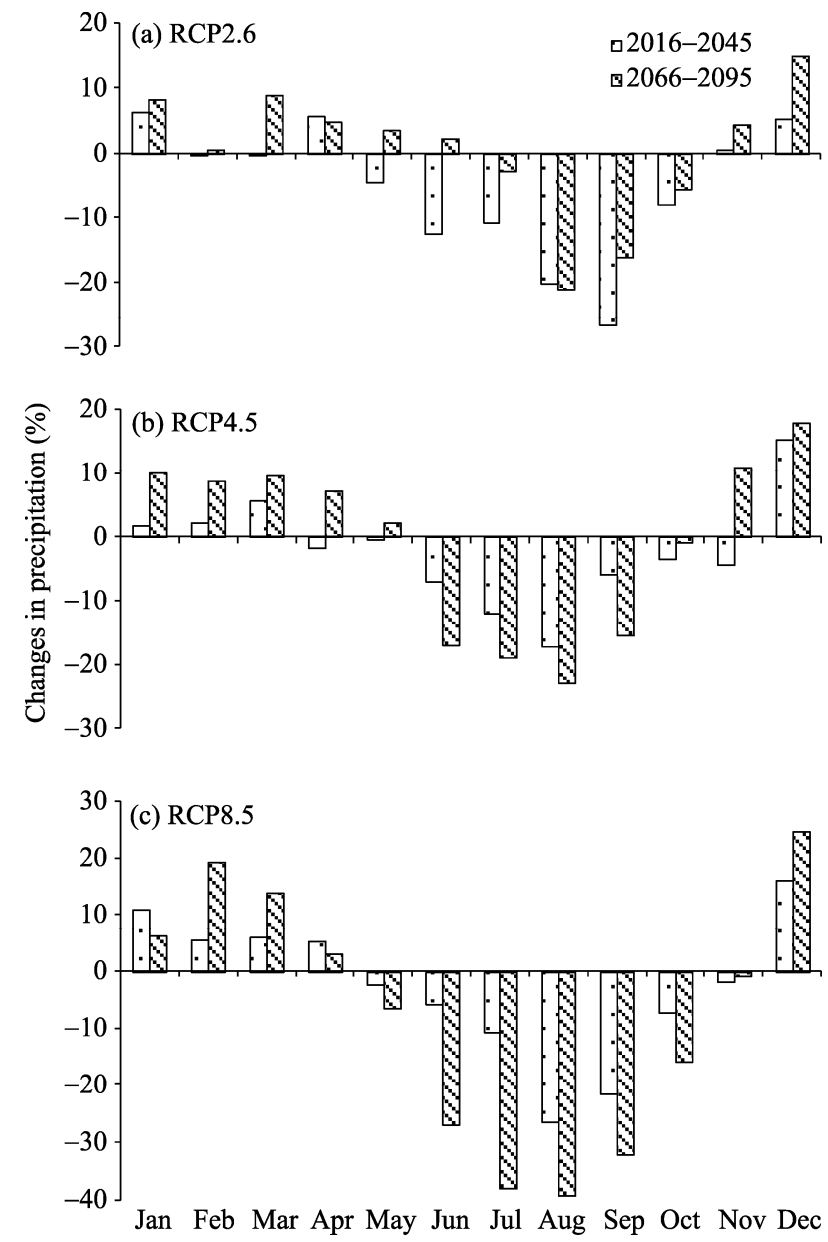

Fig. 5 Changes in mean monthly precipitation in percentage for the future periods of 2016-2045 and 2066-2095 relative to the baseline period 1966-1995 under RCP2.6 (a), RCP4.5 (b) and RCP8.5 (c) scenarios

An increase in glacial runoff will occur only in the very early melt seasons due to higher winter snow accumulation (Figs. 6d-f). Thereafter, the glacial runoff in the future is projected to be less than that in the baseline period. Monthly maximum of future glacial runoff under all the scenarios will drop sharply compared with the baseline period. Also the timing of the peak values will happen earlier in the future under RCP8.5 scenario than before. The results suggest glacier meltwater contribution to streamflow will increase in the early spring in the future, however, other seasons will see decreased contribution significantly.

Seasonal distribution of streamflow will change significantly due to climate change (Figs. $6 \mathrm{~g}-\mathrm{i}$ ). Slight increases are noted in monthly streamflow during March through May under all future climate change 

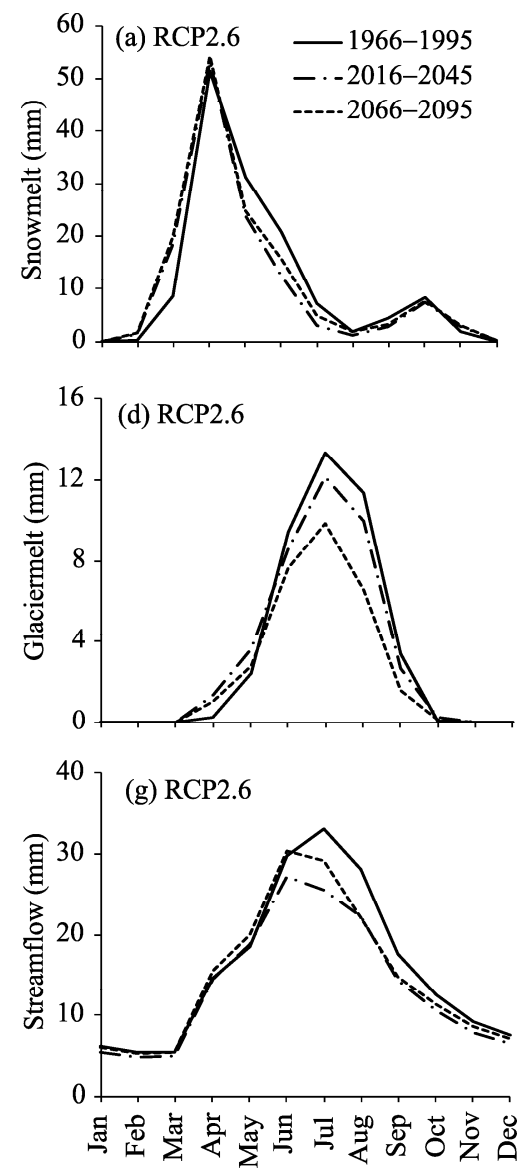

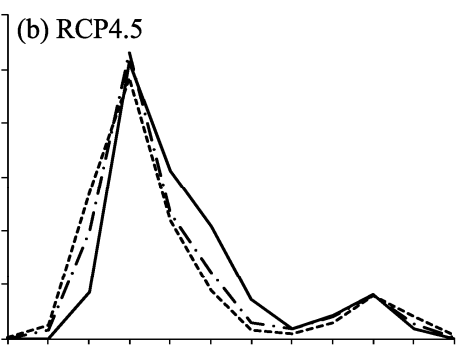

(e) RCP4.5

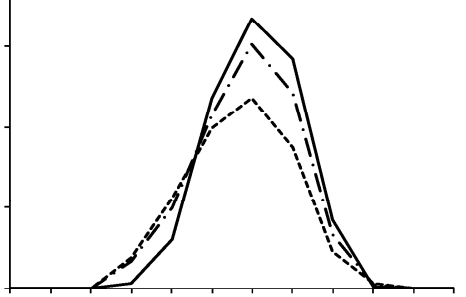

(h) RCP4.5

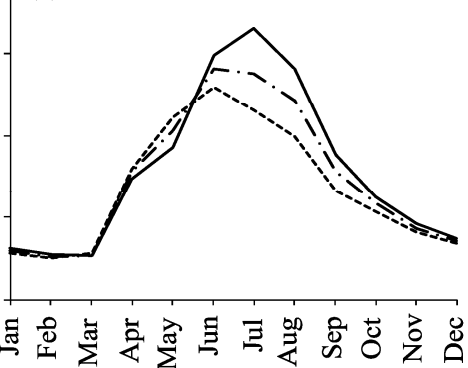

(c) RCP8.5

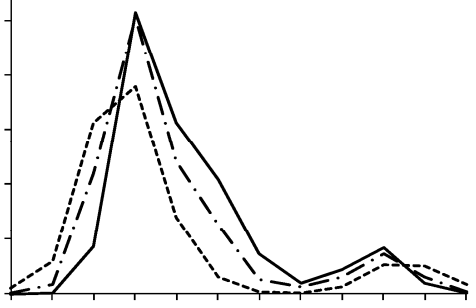

(f) RCP8.5

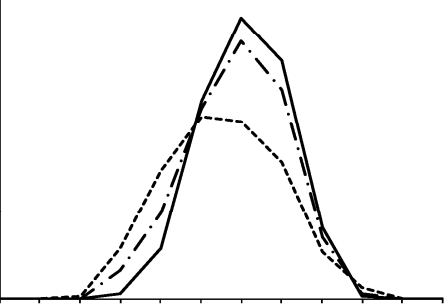

(i) RCP8.5

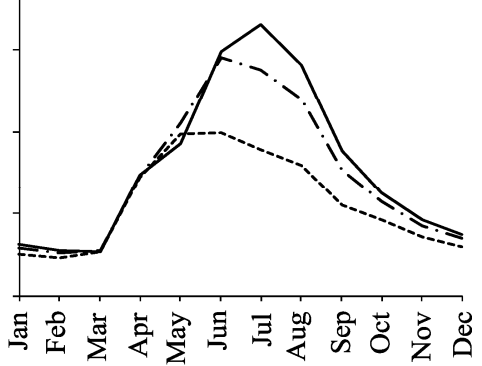

Fig. 6 Comparison of mean monthly snowmelt $(a-c)$, glaciermelt $(d-f)$ and streamflow $(g-i)$ for the future periods of $2016-2045$ and 2066-2095 relative to the baseline period 1966-1995 under RCP2.6, RCP4.5 and RCP8.5 scenarios

scenarios, mainly driven by the increases in precipitation and earlier snow and glacier melts during this period. Irrespectively, the distribution of the monthly streamflow will become flattened with lower peak values and much less discharge in summer and autumn. This is attributed to the significant decreases in precipitation and in meltwater contribution to streamflow during these seasons.

It was also noted that tremendous decrease in river runoff will happen under the strong radiative forcing scenarios. The similar trends have also been identified in other river basins in Central Asia (Hagg et al., 2007; Olsson et al., 2010). The timing of the maximum streamflow will occur approximately one month earlier in the future than in the baseline period (Figs. 6g-i). The early shift in the timing of the maximum streamflow is consistent with other findings in the headwater catchments of Syr-Darya and Issyk-Kul (Mamatkanov et al., 2006; Siegfried et al., 2011). This early shift is mainly attributed to the declining summer runoff, as also noted in the headwater catchment of Issyk-Kul which is near the headwater catchment of CRB (Mamatkanov et al., 2006).

\subsubsection{Decadal trends in runoff components}

Compared with values in the baseline period (1966-1995), the decreases in annual snowmelt, glaciermelt and streamflow for all the three climate change scenarios are noted in the future (Table 6). Although precipitation increases in winter and spring to some extent, snowmelt runoff will drop for all the scenarios, and the only exception is the minor increase in 2066-2095 under RCP2.6 scenario. The reduction in annual snowmelt under increasing precipitation in winter and spring is caused by the decreased annual total snowfall although temperature will increase (Tao et al., 2011; Sorg et al., 2012; Unger-Shayesteh et al., 2013).

Annual glaciermelt is expected to decrease in the 
Table 6 Changes in simulated snowmelt, glaciermelt and streamflow under RCP2.6, RCP4.5 and RCP8.5 scenarios averaged for 2016-2045 and 2066-2095 under CMIP5 model conditions

\begin{tabular}{|c|c|c|c|c|c|c|c|}
\hline \multirow{3}{*}{ Parameter } & \multirow{3}{*}{$\begin{array}{l}\text { Observed value in the } \\
\text { baseline period } \\
(1966-1995)(\mathrm{mm})\end{array}$} & \multicolumn{6}{|c|}{ Annual change relative to observed value in the baseline period (\%) } \\
\hline & & \multicolumn{3}{|c|}{ 2016-2045 } & \multicolumn{3}{|c|}{ 2066-2095 } \\
\hline & & $\mathrm{RCP} 2.6$ & RCP4.5 & RCP8.5 & RCP2.6 & $\mathrm{RCP} 4.5$ & RCP8.5 \\
\hline Precipitation & 242.8 & -7.4 & -4.7 & -5.2 & -0.9 & -5.3 & -14.5 \\
\hline Maximum & & +0.8 & +4.2 & +8.3 & +5.6 & +14.5 & +15.5 \\
\hline Minimum & & -20.0 & -13.5 & -16.4 & -4.8 & -17.6 & -32.0 \\
\hline Snowmelt & 136.1 & -6.7 & -4.1 & -5.1 & +1.1 & -6.2 & -21.4 \\
\hline Maximum & & -3.2 & +2.0 & +5.4 & +11.3 & -0.4 & -19.9 \\
\hline Minimum & & -13.3 & -12.1 & -13.1 & -5.4 & -14.2 & -28.9 \\
\hline Glaciermelt & 40.4 & -4.1 & -4.2 & -1.0 & -26.6 & -19.5 & -13.2 \\
\hline Maximum & & +10.8 & +8.1 & +8.5 & -12.8 & +10.7 & +16.2 \\
\hline Minimum & & -31.7 & -22.0 & -20.8 & -49.6 & -42.9 & -41.1 \\
\hline Streamflow & 188.0 & -13.4 & -6.4 & -6.9 & -6.5 & -13.7 & -27.7 \\
\hline Maximum & & -4.6 & +7.8 & +9.5 & +3.6 & +14.1 & +8.0 \\
\hline Minimum & & -22.2 & -18.6 & -20.1 & -18.6 & -37.1 & -51.6 \\
\hline
\end{tabular}

future for all the climate change scenarios with slightly larger decrease under stronger radiative forcing scenarios. Glacial runoff reduction is mainly a response to shrinking glaciers under warming climate. Obvious reduction of glacial runoff will occur in 2066-2095 under RCP2.6 condition.

Future streamflow will also tend to decrease significantly. Under RCP2.6 scenario, annual streamflow will steadily decrease with the lowest flow between 2016 and 2045 before rebounding far in the future. Under RCP4.5 and RCP8.5 scenarios, similar decrease will happen in annual streamflow. A distant future reduction as high as $27.7 \%$ is expected under RCP8.5 scenario. This is attributed to significant decrease in precipitation and glacial runoff along with increased evapotranspiration due to high temperatures.

Significant uncertainty in the GCM-projected temperature and precipitation may be the main source of uncertainties in the simulated hydrological processes (Table 6). To assess this uncertainty, we calculated mean values of the projected precipitation and hydrological processes for 2016-2045 and 2066-2095 under each GCM scenario used in this study. The maximum, minimum and mean values are given in Table 6 . The uncertainty level is alarming as the changes in the GCM-projected precipitation and hydrological processes had opposite signs with the baseline values. The significant uncertainty underscored the need for using multiple GCM outputs to drive model simulations of future conditions. It also underscored the need for using ensemble means of the models in analyzing changing trends in future scenarios. This could also include the selection of proper GCM conditions for projecting future climate change. This is fundamentally critical in investigating the impacts of climate change on catchment hydrology.

\section{Conclusions}

The glacier-hydrology enhanced SWAT-RSG model simulated future hydrological processes driving by GCM outputs under different climate change scenarios. Based on the outputs of the selected five GCM models, precipitation will decrease while temperature will increase through the end of this century in the headwater catchment of CRB, Tianshan Mountains.

The catchment hydrological processes will experience significant changes under predicted changes in temperature and precipitation. Our results highlight the decrease in annual snow and glacial runoff together with streamflow during 2016-2045 and 2066-2095. Compared with the baseline condition of 1966-1995, the changes in snowmelt, glaciermelt and streamflow in the future range from $-21.4 \%$ to $+1.1 \%,-26.6 \%$ to $-1.0 \%$ and $-27.7 \%$ to $-6.6 \%$, respectively. Furthermore, the timing of the projected maximum streamflow in the far-future period is approximately one 
month earlier than that in the baseline period. This is mainly due to the declined precipitation in the study area during summer seasons.

The above conclusions were drawn from the means of the ensembles of the five selected GCM outputs. Uncertainties in temperature and precipitation projection were induced by different GCM outputs and thus the simulated hydrological outputs were significant. Thus cautions were advised on the proper selection of GCM outputs for use in projecting future climate conditions. This was fundamentally critical for investigating the impacts of climate change on catchment hydrology.

\section{Acknowledgements}

The research was funded by International Science \& Technology Cooperation Program of China (2010DFA92720), the Project of the National Eleventh-Five Year Research Program of China (2012BAC19B07) and the National Natural Science Foundation of China (41130641).

\section{References}

Aizen V B, Aizen E M, Melack J M, et al. 1997. Climatic and hydrologic changes in the Tien Shan, Central Asia. Journal of Climate, 10: 1393-1404.

Aizen V B, Kuzmichenok V A, Surazakov A B, et al. 2007. Glacier changes in the Tien Shan as determined from topographic and remotely sensed data. Global and Planetary Change, 56(3-4): 328-340.

Anandhi A, Frei A, Pierson D C, et al. 2011. Examination of change factor methodologies for climate change impact assessment. Water Resources Research, 47(3), W03501, doi: 10.1029/2010WR009104.

Anderson J R, Hardy E E, Roach J T, et al. 1976. A Land Use and Land Cover Classification System for Use with Remote Sensor Data. Washington: United States Government Printing Office.

Arnell N W, Livermore M J L, Kovats S, et al. 2004. Climate and socio-economic scenarios for global-scale climate change impacts assessments: characterising the SRES storylines. Global Environmental Change, 14(1): 3-20.

Chen F, Huang W, Jin L, et al. 2011. Spatiotemporal precipitation variations in the arid Central Asia in the context of global warming. Science China Earth Sciences, 54(12): 1812-1821.

Chen J, Ohmura A. 1990. Estimation of alpine glacier water resources and their change since the 1870s. In: Hydrology in Mountainous Regions: I. Hydrologic Measurements, the Water Cycle. Proceedings of the Two Lausanne Symposia. Wallingford: IAHS Press, 193: $127-135$.

Cruz R V H, Harasawa M, LaI S, et al. 2007. Climate Change 2007: Impacts, Adaptation and Vulnerability. Contribution of Working Group II to the Fourth Assessment Report of the Intergovernmental Panel on Climate Change. Cambridge: Cambridge University Press,
469-506.

Cui Y H, Ye B S, Wang J, et al. 2010. Analysis of the spatial-temporal variations of the positive degree-day factors on the Glacier No.1 at the headwaters of the Urumqi River. Journal of Glaciology and Geocryology, 32(2): 265-274. (in Chinese)

Dufresne J L, Foujols M A, Denvil S, et al. 2013. Climate change projections using the IPSL-CM5 Earth System Model: from CMIP3 to CMIP5. Climate Dynamics, 40(9-10): 2123-2165.

Gassman P W, Reyes M R, Green C H, et al. 2007. The soil and water assessment tool: historical development, applications, and future research directions. Transactions of the ASABE, 50(4): 1211-1250.

Gassman P W, Sadeghi A M, Srinivasan R. 2014. Applications of the SWAT model special section: overview and insights. Journal of Environmental Quality, 43: 1-8.

Gent P R, Danabasoglu G, Donner L J, et al. 2011. The community climate system model version 4. Journal of Climate, 24(19): 4973-4991.

Giorgetta M A, Jungclaus J, Reick C H, et al. 2013. Climate and carbon cycle changes from 1850 to 2100 in MPI-ESM simulations for the Coupled Model Intercomparison Project phase 5. Journal of Advances in Modeling Earth Systems, 5(3): 572-597.

Hagg W, Braun L N, Weber M, et al. 2006. Runoff modelling in glacierized Central Asian catchments for present-day and future cliamte. Nordic Hydrology, 37(2): 93-105.

Hagg W, Braun L N, Kuhn M, et al. 2007. Modelling of hydrological response to climate change in glacierized Central Asian catchments. Journal of Hydrology, 332(1-2): 40-53.

Hu Z, Zhang C, Q S H, et al. 2014. Temperature changes in Central Asia from 1979 to 2011 based on multiple datasets. Journal of Climate, 27(3): 1143-1167.

Huang S, Krysanova V, Österle H, et al. 2010. Simulation of spatiotemporal dynamics of water fluxes in Germany under climate change. Hydrological Processes, 24(23): 3289-3306.

Immerzeel W W, van Beek L P H, Bierkens M F P. 2010. Climate change will affect the Asian water towers. Science, 328(5984): 1382-1385.

IPCC. 2007. Climate Change 2007: Synthesis Report. Contribution of Working Groups I, II and III to the Fourth Assessment Report of the Intergovernmental Panel on Climate Change. Geneva: IPCC.

Li B F, Chen Y N, Chen Z S, et al. 2013. Variations of temperature and precipitation of snowmelt period and its effect on runoff in the mountainous areas of Northwest China. Journal of Geographical Sciences, 23(1): 17-30.

Luo Y, Arnold J, Liu S, et al. 2013. Inclusion of glacier processes for distributed hydrological modeling at basin scale with application to a watershed in Tianshan Mountains, northwest China. Journal of Hydrology, 477: 72-85.

Lutz A F, Immerzeel W W, Gobiet A, et al. 2013. Comparison of climate change signals in CMIP3 and CMIP5 multi-model ensembles and implications for Central Asian glaciers. Hydrology and Earth System Sciences, 17(9): 3661-3677.

Malsy M, Aus der Beek T, Eisner S, et al. 2012. Climate change impacts on Central Asian water resources. Advances in Geosciences, 32: 77-83. 
Mamatkanov D M, Bazhanova L V, Romanovskiy V V. 2006. Water Resources of Kyrgyzstan in the Recent Period. Ilim, Bishkek. (in Russian)

Meehl G A, Covey C, Delworth T, et al. 2007. The WCRP CMIP3 multimodel dataset: a new era in climate change research. Bulletin of the American Meteorological Society, 88(9): 1383-1394.

Mengistu D T, Sorteberg A. 2012. Sensitivity of SWAT simulated streamflow to climatic changes within the Eastern Nile River basin. Hydrology and Earth System Sciences, 16(2): 391-407.

Moriasi D N, Arnol J G, Van Liew M W, et al. 2007. Model evaluation guidelines for systematic quantification of accuracy in watershed simulations. Transactions of the ASABE, 50(3): 885-900.

Narama C, Kääb A, Duishonakunov M, et al. 2010. Spatial variability of recent glacier area changes in the Tien Shan Mountains, Central Asia, using Corona ( 1970), Landsat ( 2000), and ALOS ( 2007) satellite data. Global and Planetary Change, 71(1-2): 42-54.

Nash J E, Sutcliffe J V. 1970. River flow forecasting through conceptual model part I: a discussion of principles. Journal of Hydrology, 10(3): 282-290.

Neitsch S L, Arnold J G, Kiniry J R, et al. 2005. Soil and Water Assessment Tool Theoretical Documentation Version 2005. Grassland, Soil and Water Research Laboratory, Agriculture Research Services, Texas, USA.

Olsson O, Gassmann M, Wegerich K, et al. 2010. Identification of the effective water availability from streamflows in the Zerafshan river basin, Central Asia. Journal of Hydrology, 390(3-4): 190-197.

Rossi C G, Dybala T J, Moriasi D N, et al. 2008. Hydrologic calibration and validation of the Soil and Water Assessment Tool for the Leon River watershed. Journal of Soil and Water Conservation, 63(6): 533-541.

Saxton K E, Rawls W J. 2006. Soil water characteristic estimates by texture and organic matter for hydrologic solutions. Soil Science Society of America Journal, 70(5): 1569-1578.

Scoccimarro E, Gualdi S, Bellucci A, et al. 2011. Effects of tropical clones on ocean heat transport in a high-resolution coupled general circulation model. Journal of Climate, 24(16): 4368-4384.

Sherrield J, Goteti G, Wood E F. 2006. Development of a 50-year high-resolution global dataset of meteorological forcing for land surface modeling. Journal of Climate, 19(13): 3088-3111.

Siegfried T, Bernauer T, Guiennet R, et al. 2011. Will climate change exacerbate water stress in Central Asia? Climatic Change, 112(3-4): 881-899.

Sorg A, Bolch T, Stoffel M, et al. 2012. Climate change impacts on glaciers and runoff in Tien Shan (Central Asia). Nature Climate Change, 2(10): 725-731.

Tao H, Gemmer M, Bai Y, et al. 2011. Trends of streamflow in the Tarim River Basin during the past 50 years: human impact or climate change? Journal of Hydrology, 400(1-2): 1-9.

Unger-Shayesteh K, Vorogushyn S, Farinotti D, et al. 2013. What do we know about past changes in the water cycle of Central Asian headwaters? A review. Global and Planetary Change, 110: 4-25.

Vaghefi S A, Mousavi S J, Abbaspour K C, et al. 2014. Analyses of the impact of climate change on water resources components, drought and wheat yield in semiarid regions: Karkheh River Basin in Iran. Hydrological Processes, 28(4): 2018-2032.

Voldoire A, Sanchez-Gomez E, Salas y Mélia D, et al. 2011. The CNRM-CM5.1 global climate model: description and basic evaluation. Climate Dynamics, 40(9-10): 2091-2121.

Wu J, Luo Y, Li J, et al. 2014. Evaluation of CMIP5 modes's simulation ability in the northwest arid areas of China. Arid Land Geography, 37(3): 499-508. (in Chinese)

Yatagai A, Kamiguchi K, Arakawa O, et al. 2012. APHRODITE: Constructing a long-term daily gridded precipitation dataset for Asia based on a dense network of rain gauges. Bulletin of the American Meteorological Society, 93(9): 1401-1415.

Zhang Y, Liu S Y, Ding Y J. et al. 2006. Observed degree-day factors and their spatial variation on glaciers in western China. International Glaciological Society, 43(1): 301-306. 